Neyland, M., Dunkel, P. \& Schade, A. L. (1952). J. gen. Microbiol. 7, 409-416.

\title{
The Uptake of Cobalt by Proteus vulgaris
}

\author{
By MARJORIE NEYLAND, PATRICIA DUNKEL AND A. L. SCHADE \\ Overly Biochemical Research Foundation, Inc., New York 1, New York
}

SUMMARY: Proteus vulgaris, suspended in meat extract broth or in a defined medium, bound cobalt to an extent dependent on the cell concentration and on the concentration of cobalt in the medium. An increase in concentration of cobalt or a decrease in the number of cells per unit volume resulted in a greater amount of cobalt ion bound per unit of cellular material. The composition of the suspending medium with regard to the cobalt combining groups present, as well as the availability of other metallic ions, markedly affected the amount of cobalt bound by the cells. Magnesium was particularly effective in diminishing the cobalt-combining capacity of the cells. An exposure time of $15 \mathrm{~min}$. was sufficient for the major portion of the ion to be taken up by the cells. In an anaerobic medium, the cells bound approximately one-half as much cobalt as in an aerobic medium. Raising the $\mathrm{pH}$ value of the medium from 5.0 to $7 \cdot 0$ resulted in an increased uptake of the metal by the cells. Cobalt taken up by the cells could be removed to an extent of $70-80 \%$ by dilution in distilled water and almost completely by $0 \cdot 1 \mathrm{~N}-\mathrm{HCl}$. A derived strain of Proteus, eapable of growth in relatively high concentrations of cobalt, bound smaller quantities of the ion at each level tested than did the parent strain. However, at the growth inhibitory level peculiar to each strain, the resistant form took up a much greater quantity of the metal than did the sensitive strain. This fact indicates that resistance to cobalt cannot be explained merely on the basis of the cobalt-concentrating ability of the cells.

The growth inhibitive action of cobalt on various bacteria and especially on Proteus vulgaris has been studied as a function of the composition of the growth medium, strain sensitivity, age of culture, size of inoculum, and other cultural conditions (Schade, 1949). Further, the effect of cobalt on the relationship between nucleic acid concentration and growth rate in the nucleic acids of $\boldsymbol{P}$. vulgaris have been determined (Levy, Skutch \& Schade, $1949 a, b)$. Employing radio-isotope techniques, we have now investigated the uptake of cobalt by the cells of $\boldsymbol{P}$. vulgaris under various environmental conditions in an effort to determine the principal factors involved in the binding of the metal.

\section{METHODS}

The organism employed in these studies was a strain of $\boldsymbol{P}$. vulgaris isolated originally from a case of cystitis and maintained on meat extract agar slopes of the composition: $0.3 \%(\mathrm{w} / \mathrm{v})$ Difco meat extract; $1.0 \%(\mathrm{w} / \mathrm{v})$ Difco peptone; $0.5 \%(\mathrm{w} / \mathrm{v}) \mathrm{NaCl} ; 3.0 \%(\mathrm{w} / \mathrm{v})$ Difeo agar; adjusted to $\mathrm{pH} 7.5$ with $\mathrm{NaOH}$.

Cells from 18 to $24 \mathrm{hr}$. slope cultures were washed with either distilled water or 0.001 м potassium phosphate buffer, $\mathrm{pH} 7 \cdot 3$. The cell suspensions, made up to the desired turbidity, were then inoculated into the test medium containing cobalt as $\mathrm{CoSO}_{4} \cdot 7 \mathrm{H}_{2} \mathrm{O}$ and $0.03-0.07 \mu \mathrm{c} . / \mathrm{ml}$. of radio-active cobalt 60 as 


\section{Marjorie Neyland, Patricia Dunkel and A. L. Schade}

$\mathrm{CoCl}_{2}$. Following incubation in a water-bath at $37^{\circ}$, the radio-active cell suspensions were spun down in a Sorvall high-speed centrifuge in weighed $15 \mathrm{ml}$. glass centrifuge tubes. The supernatants were poured off and saved for determination of radio-activity. The tubes were then drained and weighed. From the known wet weight of cells calculated from the turbidity measurement, the amount of supernatant remaining in the tubes could be determined by difference. The cells were then suspended in $1.0 \mathrm{ml} .0 \cdot 1 \mathrm{~N}-\mathrm{HCl}$ and determinations of radio-activity made on $\mathbf{0 . 2} \mathrm{ml}$. portions of the acid cell suspensions and of their original supernatants. The samples to be assayed were pipetted on to glass cover-slips previously moistened with a drop of detergent $(1 \%$ Duponol, Dupont) to ensure even distribution of the radio-active sample. The total quantity of liquid was contained within a ring of Dow Corning heavy silicone stopcock grease. Samples thus prepared were dried under an infra-red lamp and counted with a Geiger-Müller counter.

\section{RESULTS}

Cobalt uptake as affected by the concentration of cobalt and cells in the medium

In previous studies of the inhibitive action of cobalt on the growth of $\boldsymbol{P}$. vulgaris, we found that the extent of inhibition was conditioned by the concentration of cobalt in the medium and by the size of the inoculum. In a defined medium, $0 \cdot 12 \mu \mathrm{g}$. $\mathrm{Co}^{++} / \mathrm{ml}$. was sufficient to prevent the growth of approximately 1000 cells $/ \mathrm{ml}$. At the same level of cobalt concentration, cultures containing 10,000 cells $/ \mathrm{ml}$. showed only partial inhibition and those containing 100,000 cells/ml. grew out to a degree equal to control cultures without cobalt.

To determine to what extent the amount of cobalt taken up by $P$. vulgaris was affected by the concentration of cobalt and the number of cells in a given volume of medium, we performed a number of experiments in which both of these factors were varied. In one set of experiments, a given weight of cells was exposed to increasing quantities of cobalt contained in equal volumes of 1:5 meat extract broth (MEB). Under these conditions, a fair degree of correlation was found between concentration of cobalt in the medium and uptake of the metal by the cells. The results of a typical experiment are summarized in Table 1. From these data, it is evident that an increase in the level of cobalt from 1 to $10 \mu \mathrm{g} . / \mathrm{ml}$. resulted in close to a tenfold increase in the amount of cobalt bound per mg. dry weight of cells. At the higher concentra-

\section{Table 1. Uptake of cobalt as affected by concentration of $\mathrm{Co}^{++}$in the medium}

One mg. dry wt. cells suspended in $30.0 \mathrm{ml}$. of $1: 5 \mathrm{MEB}$, pH 7.3 containing $1 \cdot 0 \mu \mathrm{c}$. radioactive ${ }^{60} \mathrm{Co}^{++}$and varying quantities of $\mathrm{CoSO}_{4} .7 \mathrm{H}_{2} \mathrm{O}$ to give the required concentration. Time of exposure $1 \mathrm{hr}$. at $37^{\circ}$.

$\begin{array}{ccc}\begin{array}{c}\text { Co }^{++} \\ \text {concentration } \\ (\mu \mathrm{g} . / \mathrm{ml} .)\end{array} & \begin{array}{c}\text { Dry wt. } \\ \text { of cells } \\ (\mathrm{mg} / \mathrm{ml} .)\end{array} & \begin{array}{c}\mathrm{Co}^{++} \text {uptake } \\ \left(\mu \mathrm{g} . \mathrm{Co}^{++} / \mathrm{mg} .\right. \\ \text { dry wt. cells })\end{array} \\ 1 & 0.033 & 0 \cdot 237 \\ 10 & 0.033 & 2 \cdot 12 \\ 100 & 0.033 & 15 \cdot 3\end{array}$


tion of $100 \mu \mathrm{g} . \mathrm{Co}^{++} / \mathrm{ml}$., the increased uptake by the cells was no longer directly proportional.

When the concentration of cobalt was maintained at a constant level and the number of cells altered by the addition of varying dilutions of a stock-cell suspension, an inverse relationship was found between the amount of cobalt taken up per unit weight of cells and the concentration of cells in the medium. The results of two of such experiments are given in Table 2. The ability of the cells to concentrate high amounts of cobalt per unit of cellular material is particularly evident in those instances where the total cell number was low. The capacity of relatively low concentrations of cells to take up large quantities of cobalt was found also in experiments where variation in cell concentration was achieved in a different manner. In such tests, $0.5 \mathrm{mg}$. dry wt. of cells exposed to $100 \mu \mathrm{g}$. $\mathrm{Co}^{++} / \mathrm{ml}$. in 6.0 ml. 1:5 MEB took up approximately $19 \mu \mathrm{g}$. $\mathrm{Co}^{++} / \mathrm{mg}$. dry wt. cells, while the same weight of cells suspended in $30 \mathrm{ml}$. of this medium containing $100 \mu \mathrm{g}$. $\mathrm{Co}^{++} / \mathrm{ml}$. took up as much as $68 \mu \mathrm{g}$. $\mathrm{Co}^{++} / \mathrm{mg}$. dry wt. cells.

Table 2. Uptake of cobalt as affected by concentration of cells in the medium

Varying dilutions of a stock cell suspension were inoculated into $35 \mathrm{ml}$. of $1: 5 \mathrm{MEB}$, $\mathrm{pH} 7 \cdot 3$ containing $1 \cdot 4 \mu \mathrm{c}$. radio-active cobalt ${ }^{60} \mathrm{Co}^{++}$in a final concentration of $100 \mu \mathrm{g} \cdot \mathrm{Co}^{++} / \mathrm{ml}$. Time of exposure $1 \mathrm{hr}$. at 37.

$\begin{array}{rcc}\text { Cell conc. } & \begin{array}{c}\text { Total dry wt. } \\ \text { of cells } \\ (\mathbf{m g} .)\end{array} & \begin{array}{c}\mathrm{Co}^{++} \text {uptake } \\ \left(\mu \mathrm{g} . \mathrm{Co}^{++} / \mathrm{mg} .\right. \\ \text { dry wt. cells })\end{array} \\ (a) \times 1 & 0 \cdot 093 & 86 \cdot 4 \\ \times 5 & 0 \cdot 464 & 10 \cdot 0 \\ \times 24 & 2 \cdot 24 & 4 \cdot 92 \\ (b) \times 1 & 0 \cdot 130 & 51 \cdot 5 \\ \times 4.7 & 0 \cdot 612 & 8 \cdot 81 \\ \times 23 \cdot 3 & 3 \cdot 024 & 5 \cdot 14\end{array}$

It can be noted here that in comparing different groups of inocula the actual amount of cobalt bound/unit of cell material varied, even though inocula of comparable age and size were exposed to the same concentration of cobalt. This variability of different inocula in their response to cobalt makes it difficult to obtain quantitative data necessary for elucidating the method whereby cell concentration affects the amount of cobalt bound.

Consideration of the data of Tables 1 and 2 led us to anticipate that if the concentrations of both cobalt and cells were simultaneously increased to the same degree, the observed uptake of cobalt by the cells would be the resultant of these two opposing factors. Such an experiment was set up by exposing equal quantities of cells to a given weight of cobalt contained in different volumes of suspending medium. The results summarized in Table 3 show that a decrease in the amount of cobalt bound/unit of cell material occurs as the concentration of both cobalt and cells is diminished. The amount of cobalt associated with the cells will be affected to a greater extent by a change in the concentration of cobalt in the medium than by an equivalent change in the concentration of cells. 
Table 3. Uptake of cobalt varying both $\mathrm{Co}^{++}$and cell concentration

$2 \cdot 0,8.0,32.0 \mathrm{ml} .0 .9 \% \mathrm{NaCl}$ in $0.01 \mathrm{~m}$ sodium acetate, $\mathrm{pH} 6.0$, containing: $(a) 32 \mu \mathrm{g}$. cobalt, $0.5 \mu \mathrm{c}$. radio-active cobalt, $0 \cdot 196 \mathrm{mg}$. dry wt./cells; $(b) 2 \mu \mathrm{g}$. cobalt, $1 \cdot 0 \mu \mathrm{c}$. radio-active cobalt, $0 \cdot 223 \mathrm{mg}$. dry wt. cells.

\begin{tabular}{|c|c|c|c|}
\hline \multicolumn{2}{|c|}{$\begin{array}{c}\mathrm{Co}^{++} \\
\text {concentration } \\
(\mu \mathrm{g} . / \mathrm{ml} .)\end{array}$} & $\begin{array}{c}\text { Cell } \\
\text { concentration } \\
(\mu \mathrm{g} . \text { dry wt./ml. })\end{array}$ & $\begin{array}{l}\mathrm{Co}^{++} \text {uptake } \\
\left(\mu \mathrm{g} . \mathrm{Co}^{++} / \mathrm{mg} .\right. \\
\text { dry wt. cells })\end{array}$ \\
\hline \multirow[t]{3}{*}{ (a) } & 16 & 98 & $0 \cdot 810$ \\
\hline & 4 & $24 \cdot 5$ & $0 \cdot 369$ \\
\hline & 1 & $6 \cdot 1$ & $0 \cdot 298$ \\
\hline \multirow[t]{3}{*}{ (b) } & 1 & 112 & 0.102 \\
\hline & 0.25 & $27 \cdot 9$ & 0.0349 \\
\hline & $0 \cdot 0616$ & 6.97 & 0.0171 \\
\hline
\end{tabular}

\section{Cobalt uptake as affected by the constituents of the suspending medium}

Early in our work we had observed that the amount of cobalt taken up by the cells exposed to $10 \mu \mathrm{g}$. $\mathrm{Co}^{++} / \mathrm{ml}$. in a growth medium $(1: 5 \mathrm{MEB})$ was approximately one-third that taken up by an equal weight of cells in $0.001 \mathrm{M}$ potassium phosphate buffer. The possibility that the metabolic state of the cells in a growth medium compared to that of cells in phosphate buffer might be reflected in their cobalt-combining capacity was investigated. Since, however, the MEB has cobalt-combining constituents which could compete with the cells for the free cobalt ions and thus effect a diminished uptake of cobalt by the cells, we employed a defined growth medium free of cobalt-combining substances. In a medium containing $0 \cdot 1 \%(\mathrm{w} / \mathrm{v})$ glucose, $0 \cdot 1 \%(\mathrm{w} / \mathrm{v})$ $\left(\mathrm{NH}_{4}\right)_{2} \mathrm{SO}_{4}, 30 \mu \mathrm{g} . / \mathrm{ml}$. nicotinamide, $100 \mu \mathrm{g} . / \mathrm{ml}$. $\mathrm{MgSO}_{4} .7 \mathrm{H}_{2} \mathrm{O}$ in $0.001 \mathrm{M}-$ $\mathrm{K}_{2} \mathrm{HPO}_{4} \mathrm{pH} 7 \cdot 3$ the uptake of cobalt by the cells was again considerably less (one-third to one-quarter) than that shown by cells suspended in phosphate buffer alone. The removal of glucose and/or $\left(\mathrm{NH}_{4}\right)_{2} \mathrm{SO}_{4}$ from the complete medium did not significantly alter the amount of cobalt bound by the cells. Further, when an aged inoculum of viability less than $0.001 \%$ was used, a similar difference was again found in the amount of cobalt bound by these cells in the complete defined medium and in $0.001 \mathrm{M}-\mathrm{K}_{2} \mathrm{HPO}_{4}$. From these results, it appeared doubtful whether the change in metabolic state associated with the ability of the cells to reproduce themselves would account for the wide differences found in cobalt uptake.

\section{Antagonistic action of magnesium}

We next investigated the effect of magnesium on the amount of cobalt taken up by the cells. When magnesium was added to the phosphate buffer in a concentration equivalent to that used in the defined medium, $10 \mu \mathrm{g} . \mathrm{Mg}^{++} / \mathrm{ml}$., a marked decrease in the amount of cobalt bound by the cells was observed. Increasing the concentration of $\mathrm{Mg}^{++}$from 10 to $1000 \mu \mathrm{g} . / \mathrm{ml}$. resulted in a further diminished uptake of cobalt by the cells (Table 4). The extent of the antagonism was such that between the limits of 10 and $1000 \mu \mathrm{g} . \mathrm{Mg}^{++} / \mathrm{ml}$, a tenfold increase in the concentration of magnesium resulted in nearly a fourfold decrease in the amount of cobalt bound by the cells. Independent 
studies of the extent of growth inhibition effected by cobalt at increasing levels of magnesium in the defined medium showed that as the concentration of magnesium in the medium was raised, increased concentrations of cobalt were required to prevent growth of the cells.

Table 4. Cobalt uptake as affected by concentration of magnesium in the medium

$0.618 \mathrm{mg}$. dry wt. cells inoculated into $10.0 \mathrm{ml}$. $0.001 \mathrm{~m}-\mathrm{K}_{2} \mathrm{HPO}_{4}, \mathrm{pH} 7 \cdot 4$, containing $0.4 \mu \mathrm{c}$. radio-active cobalt in final concentration of $10 \mu \mathrm{g} . \mathrm{CO}^{++} / \mathrm{ml}$. and varying concentrations of $\mathrm{Mg}^{++}$as $\mathrm{MgSO}_{4} \cdot 7 \mathrm{H}_{2} \mathrm{O}$. 'Time of incubation $1 \mathrm{hr}$. at $37^{\circ}$.

$\begin{array}{ccc}\begin{array}{c}\text { Concentration } \\ \text { of } \mathrm{Mg}^{++} \\ (\mu \mathrm{g} . / \mathrm{ml} .)\end{array} & \begin{array}{c}\text { Conc. } \\ \text { of cells } \\ \text { (mg. dry wt./ml.) }\end{array} & \begin{array}{c}\mathrm{Co}^{++} \text {uptake } \\ \left(\mu \mathrm{g} . \mathrm{Co}^{++} / \mathrm{mg} .\right. \\ \text { dry wt. cells })\end{array} \\ 10 & 0.06 & 18 \cdot 3 \\ 100 & 0.06 & 7.68 \\ 1000 & 0.06 & 1.90 \\ & 0.06 & 0.48\end{array}$

Cobalt uptake under anaerobic conditions

The uptake of cobalt by cells of $\boldsymbol{P}$. vulgaris under anaerobic conditions was studied by passing a continuous stream of oxygen-free nitrogen gas through the inoculated medium $(1: 5 \mathrm{MEB})$ contained in $50 \mathrm{ml}$. capacity plastic centrifuge tubes. Oxygen-free solutions of cobalt were added by means of a syringe. Control tubes were treated in an identical manner but with the nitrogen gas replaced by compressed air. At the end of the incubation period the tubes were capped immediately to maintain the gas phase unchanged during time of centrifugation.

\section{Table 5. Uptake of cobalt under anaerobic conditions}

$20 \mathrm{ml}$. 1:5 MEB containing 1.0 $\mu \mathrm{c}$. radio-active cobalt in final concentrations of $50 \mu \mathrm{g}$. $\mathrm{Co}^{++} / \mathrm{ml}$., inoculated with: (a) $2.76 \mathrm{mg}$. dry wt. of cells; (b) $4.2 \mathrm{mg}$. dry wt. cells. Incubation period $1 \mathrm{hr}$, at $37^{\circ}$.

$\begin{array}{ccc}\text { Gas phase } & \begin{array}{c}\text { Cell } \\ \text { concentration } \\ \text { (mg. dry wt./ml. })\end{array} & \begin{array}{c}\mathrm{Co}^{++} \text {uptake } \\ \left(\mu \mathrm{g} . \mathrm{Co}^{++} / \mathrm{mg} .\right. \\ \text { dry wt. cells) }\end{array} \\ \text { (a) Air } & 0 \cdot 0138 & 4 \cdot 15 \\ \mathrm{~N}_{2} & 0 \cdot 0138 & 2 \cdot 34 \\ \text { (b) Air } & 0 \cdot 21 & 6 \cdot 6 \\ \mathrm{~N}_{2} & 0 \cdot 21 & 4 \cdot 7\end{array}$

The results of two such experiments are summarized in Table 5. In each case, sufficient cobalt ( $50 \mu \mathrm{g} . / \mathrm{ml}$.) was present in the medium to prevent growth of both aerobic and anaerobic cultures. Under these conditions, cells maintained in a nitrogen atmosphere bound less cobalt/unit of cellular material than did the cells maintained in the presence of air. These results are of interest since it has been previously found that the concentration of cobalt required for growth inhibition of anaerobic cultures of Proteus is 2 to 3 times that required to prevent growth of similar inocula cultured in air (Schade, 1949). 


\section{Marjorie Neyland, Patricia Dunkel and A. L. Schade}

Cobalt uptake by a cobalt resistant strain of $\mathbf{P}$. vulgaris

By repeated transfer of inocula of our cobalt sensitive strain of $\boldsymbol{P}$. vulgaris into media (MEB) containing increasing concentrations of cobalt, we obtained a strain capable of growth in the presence of $150 \mu \mathrm{g}$. $\mathrm{Co}^{++} / \mathrm{ml}$. The amount of cobalt bound by these adapted cells was compared with that bound by the parent strain. Tests were run in 1:5 MEB at two levels of cobalt concentration, 10 and $200 \mu \mathrm{g} . / \mathrm{ml}$, corresponding to growth inhibitory levels for the stock and cobalt-resistant strain, respectively. The results of two experiments are given in Table 6.

Although the cobalt-sensitive strain fixed approximately 1.5 times more cobalt than did the resistant strain at both levels of cobalt concentration used, the resistant strain bound, at $200 \mu \mathrm{g}$. $\mathrm{Co}^{++}$, thirty times as much cobalt as the sensitive strain bound at its growth inhibitory level of $10 \mu \mathrm{g} . \mathrm{CO}^{++} / \mathrm{ml}$. From these results, it seems doubtful whether the failure of $150 \mu \mathrm{g} . \mathrm{CO}^{++} / \mathrm{ml}$. to inhibit growth of the resistant strain can be ascribed merely to failure of the cells to bind significant quantities of the metal.

Table 6. Cobalt uptake by $\mathrm{P}$. vulgaris, comparison of stock strain with cobalt resistant variant

10.0 ml. of $1: 5 \mathrm{MEB}$ containing $\mathrm{CoSO}_{4} .7 \mathrm{H}_{2} \mathrm{O}$ in concentration of 10 and $200 \mu \mathrm{g}$. $\mathrm{Co}^{++} / \mathrm{ml}$. and $0.49 \mu \mathrm{c}$. radio-active cobalt inoculated with approximately $1.0 \mathrm{mg}$. dry wt. cells of each strain. Time of incubation $1 \mathrm{hr}$. at $37^{\circ}$.

\begin{tabular}{|c|c|c|c|c|}
\hline \multirow[b]{3}{*}{ Cell type } & \multicolumn{4}{|c|}{ Concentration of cobalt in the medium } \\
\hline & \multicolumn{2}{|c|}{$10 \mu \mathrm{g} \cdot / \mathrm{ml}$} & \multicolumn{2}{|c|}{$200 \mu \mathrm{g} \cdot / \mathrm{ml}$} \\
\hline & $\begin{array}{c}\text { Cell conc. } \\
\text { (mg. dry wt./ml.) }\end{array}$ & $\begin{array}{c}\mathrm{Co}^{++} \text {uptake } \\
\left(\mu \mathrm{g} . \mathrm{Co}^{++} / \mathrm{mg} .\right. \\
\text { dry wt. })\end{array}$ & $\begin{array}{c}\text { Cell cone. } \\
\text { (mg. dry wt./ml.) }\end{array}$ & $\begin{array}{l}\mathrm{Co}^{++} \text {uptake } \\
\left(\mu \mathrm{g} \cdot \mathrm{Co}^{++} / \mathrm{mg}\right. \\
\text { dry wt. cells })\end{array}$ \\
\hline Co R & 0.073 & 0.977 & 0.071 & $43 \cdot 6$ \\
\hline Co $\mathrm{S}$ & $0 \cdot 0 \gamma$ & $1 \cdot 432$ & 0.076 & $76 \cdot 7$ \\
\hline Co $\mathbf{R}$ & $0 \cdot 121$ & $0 \cdot 775$ & $0 \cdot 105$ & $39 \cdot 1$ \\
\hline Co S & $0 \cdot 087$ & $\mathbf{1 . 3 6 1}$ & 0.095 & $59 \cdot 9$ \\
\hline
\end{tabular}

Cobalt uptake as affected by the time of exposure and the $\mathrm{pH}$ of the medium

Employing a concentration of $100 \mu \mathrm{g}$. $\mathrm{Co}^{++} / \mathrm{ml}$. of 1:5 MEB, we determined the amount of cobalt bound by cells suspended in this medium for 15, 30, 60 and $120 \mathrm{~min}$. No significant increase in cobalt uptake by cells suspended for periods longer than 30 min. was observed; $70-80 \%$ of the maximum amount taken up could be accounted for in the cells at the end of only $15 \mathrm{~min}$. exposure.

The effect of the $\mathrm{pH}$ value of the medium on cobalt uptake by the cells was tested in $0.01 \mathrm{~m}$ potassium phosphate buffer. At concentrations of $5 \mu \mathrm{g}$. $\mathrm{CO}^{++}$ and of $0.07 \mathrm{mg}$. dry wt. cells $/ \mathrm{ml}$. medium, the amount of cobalt bound/unit of cellular material was $0.75 \mu \mathrm{g}$. at $\mathrm{pH} 5.0,1.02 \mu \mathrm{g}$. at $\mathrm{pH} 6.0$ and $1.65 \mu \mathrm{g}$. at $\mathrm{pH} \mathrm{7.0.} \mathrm{Efforts} \mathrm{to} \mathrm{test} \mathrm{the} \mathrm{effect} \mathrm{of} \mathrm{higher} \mathrm{pH}$ values on cobalt uptake in this medium were complicated by precipitation of insoluble cobalt compounds. 


\section{Removal of cobalt from the cells}

How much of the cobalt bound to the cell substance was readily removable with water or $\mathbf{H C l}$ was investigated. A quantity of cells $(1.43 \mathrm{mg}$. dry wt.) was suspended in $2.0 \mathrm{ml}$. distilled water containing $1 \mu \mathrm{c}$. radioactive cobalt in a final concentration of $10 \mu \mathrm{g}$. $\mathrm{Co}^{++} / \mathrm{ml}$. After incubation at $37^{\circ}$ for $\mathrm{I} \mathrm{hr}$. the suspensions were centrifuged, supernatants removed, and the cells washed four times by repeated centrifugation and suspension in $10 \mathrm{ml}$. distilled water. The amount of cobalt taken up by the cells prior to the first wash was determined by summation of the counts found in the supernatant of each wash and the number remaining in the washed cells. Correction for cobalt retained in adhering supernatant was made. Of a total $3.91 \mu \mathrm{g} . \mathrm{Co}^{++}$taken up by the cells, $46,32,28$ and $26 \%$ remained with the cells after the first, second, third and fourth washes, respectively. Hence, it is apparent that 20-25\% of the cobalt originally associated with the cells was bound more or less fixedly to the cellular substance.

When fresh cells exposed to similar concentrations of cobalt were subsequently suspended in $0 \cdot 1 \mathrm{~N}-\mathrm{HCl}, 95-98 \%$ of the total cobalt taken up appeared in the supernatant.

\section{DISCUSSION}

The observation that cells of $\boldsymbol{P}$. vulgaris take up cobalt rapidly and that distilled water or $0 \cdot 1 \mathrm{~N}-\mathrm{HCl}$ easily remove it indicates that cobalt is primarily bound with the cell substance in a readily reversible manner. Such binding may be accomplished by the mechanism of ion adsorption with the cells acting in a manner similar to charged colloidal particles, or by direct chemical combination with reactive groups throughout the cell as well as with those found at the cell surface.

Evidence for the existence of amino-acid groups at the surface of bacterial cells has been presented by Cohen (1945). Chelation of such groups with cobalt may represent one mode of attachment of the metal to the cell. Albert (1950) measured the affinity of a number of divalent amino-acids for heavy metal ions, including cobalt, and found a degree of stability for all amino-acids: $\mathrm{Cu}^{++}>\mathrm{Ni}^{++}>\mathrm{Zn}^{++}>\mathrm{Co}^{++}>\mathrm{Cd}^{++}>\mathrm{Fe}^{++}>\mathrm{Mn}^{++}>\mathrm{Mg}^{++}$. The ability of cobalt to form complexes with histidine at physiological $\mathrm{pH}$ values has been shown by Hearon, Burk \& Schade (1949). The first reaction product formed, cobalt dihistidine, as well as the oxygenated product oxybiscobaltodihistidine, are completely reversible with $\mathrm{HCl}$, but in time, in the presence of oxygen, the latter product is converted to an irreversible complex. It is conceivable that this type of bond may in part account for the small portion of cobalt remaining in the cells of $\boldsymbol{P}$. vulgaris after treatment with HCl. Further, cobalt may be combined irreversibly with cysteine (Michaelis \& Barron, 1929).

Reversible uptake of cations from solution by bacteria has been investigated by a number of workers. McCalla (1940) studied the uptake of $\mathrm{H}^{+}$, methylene blue and $\mathrm{Mg}^{++}$by a number of soil bacteria and found, for example, that $\mathrm{Mg}^{++}$taken up by Bact. coli could be removed to a significant degree by the 


\section{Marjorie Neyland, Patricia Dunkel and A. L. Schade}

subsequent addition of $\mathrm{Co}^{++}, \mathrm{Ba}^{++}$, or $\mathrm{Mn}^{++}$. Valko \& Dubois (1944) obtained a reversal of the bactericidal action of surface-active cations by detoxification with surface-active anions or by non-toxic surface-active cations. In these instances the uptake of cations was explained as the result of adsorptive forces exhibited by the negatively charged cells.

The ability of magnesium to alter the amount of cobalt taken up by the cells of $\boldsymbol{P}$. vulgaris and to affect the concentration of cobalt required for growth inhibition may be an expression of competition of the two ions for an essential metabolic group on the cell. Abelson \& Aldous (1950) reported a similar action of magnesium for nickel as well as cobalt with Bact. coli and found that $\mathrm{Mg}^{-1+}$ exerted its effect at the time of metal uptake. The inability of magnesium to replace cobalt already bound by the cell may be due to a difference in the stability of the metal complexes formed with the cell substance.

This investigation was supported in part by a research grant from the Division of Research Grants and Fellowships of the National Institute of Health, U.S. Public Health Service.

\section{REFERENCES}

Abelson, P. H. \& Aldous, E. (1950). Ion antagonisms: interference of normal magnesium metabolism by nickel, cobalt, cadmium, zinc and manganese. J. Bact. 60, 401.

Albert, A. (1950). Quantitative studies of the avidity of naturally occurring substances for trace metals. L-Amino-acids having only two ionizing groups. Biochem. J. 47, 531.

Conen, S. S. (1945). The chemical alteration of a bacterial surface with special reference to the agglutination of B. proteus OX-19. J. exp. Med. 82, 133.

Hearon, J., Burk, D. \& Schade, A. L. (1949). Physical chemical studies of reversible and irreversible complexes of cobalt, histidine and molecular oxygen. J. nat. Cancer Inst. 9, 337.

Levy, H. B., Skutch, E. T. \& Schade, A. L. (1949a). The effect of cobalt on the relationship between nucleic acid concentration and growth rate in Proteus vulgaris. Arch. Biochem. 24, 199.

Levy, H. B., Skutch, E. T. \& Schade, A. L. (1949b). Effect of cobalt on the phosphorus turnover rate in the nucleic acids of Proteus vulgaris. Arch. Biochem. 24, 206.

McCalla, T. M. (1940). Cation adsorption by bacteria. J. Bact. 40, 23.

Michaelis, L. \& Barron, E. S. G. (1929). Comparative study of the complexes of cysteine with the metals of the iron group. J. biol. Chem. 83, 191.

Schade, A. L. (1949). Cobalt and bacterial growth with special reference to Proteus vulgaris. J. Bact. 58, 811.

Valko, E. I. \& Dubors, A. S. (1944). The antibacterial action of surface active cations. J. Bact. 47, 15. 